Reviews

\title{
Women and Microcredit in Rural Bangladesh. An Anthropological Study of Grameen Bank Lending, by Aminur Rahman. Boulder, CO: Westview Press, 1999, xi, 188 pp.
}

\author{
Review by Geeta Chowdhry, Department of Political Science, Northern Arizona \\ University.
}

Microcredit has recently become the new development mantra for international donors, international financial institutions, and national development programs. The legendary "success" of the Grameen Bank in Bangladesh, with its grassroots-based, empowerment-from-below focus that enables microcredit to straddle many ideological divides, and its resonance within the dominant development paradigms of the late twentieth and twenty-first century, has contributed to the popularity enjoyed by microcredit. Although Muhammad Yunus, a Professor at Chittagong University in Bangladesh, is the creator of Grameen Bank and microcredit lending, two distinct, yet sympathetic, scholarly and practitioner traditions can be said to have contributed to the intellectual environment in development agencies that facilitated microcredit lending -- feminist scholarship on development and critical scholarship on poverty.

A common theme of liberal feminist scholarship on development, despite the variance of such work, has been the effort to make women visible as a constituency both participating in development and being affected by development policies. Liberal feminism, also called the Women in Development (WID) approach, has offered rigorous critiques of the liberal modernization paradigm by documenting the gender biases of such approaches. However, WID has remained situated squarely within the liberal modernization approach. As a solution to the gender bias of modernization programs, WID, in its incarnation from welfare to efficiency, called on governments, development agencies and international financial institutions to provide aid and resources specifically for women, who would then be able to contribute substantively towards family welfare and national development.

The critical poverty literature has a deep historical tradition that was echoed in a limited liberal way in the 1970s in a volume edited by Hollis Chenery, Redistribution with Growth (1974). Clearly, more brilliant treatises on poverty are available, yet this book stands as a landmark in development because it epitomized the changing focus on poverty within the World Bank. Along with its focus on "distribution with growth" the book suggested that availability of resources to the poor would lead to self-employment and contribute effectively towards national development.

In 1976 Muhammad Yunus introduced the idea of the Grameen Bank in Bangladesh, which would capture the essence of the liberal feminist and poverty critiques of development by providing microcredit -- "small amounts of collateral-free institutional loans extended to jointly liable group members for self employment" (ix) -- to its clients. Originally created to provide loans to the poor, it soon began to focus on poor women. The Grameen Bank is now the largest lending institution in Bangladesh with a cumulative investment of "more than one billion U.S. dollars disbursed among 2.3 million members, 95 percent of whom are women." (1)

The Grameen Bank's success among poor rural women in Bangladesh, like SEWA for poor urban women in India, has contributed effectively to the filtering of the microcredit concept worldwide. From "a new paradigm for thinking about economic development" to being hailed as "the key element for the twenty-first century's economic and social development," it is now being incorporated in mainstream development programs $(1,12)$ and is largely seen as the vehicle for women's empowerment and the development panacea of the twenty-first century.

In Women and Microcredit in Rural Bangladesh, Aminur Rahman challenges this conventional view of microcredit. Based on thirteen months of ethnographic research with 120 women borrowers and 12 Grameen Bank local workers in the Tangail district of Bangladesh, this work provides valuable insight and adds to the rich literature available on the successes and failures of the Grameen Bank. Most scholarship on the Grameen Bank, with a few exceptions, has used survey research to focus on Bank performance. Rahman's detailed findings based on participant observation and lengthy unstructured interviews with women and bank workers cautions against an uncritical allegiance to microcredit lending, by highlighting the dynamics of power in the lending structures of the Grameen Bank, the impact of microlending on gendered power relations at the household level, obstacles to the empowerment of women, and increased levels of tensions and domestic violence towards women in the villages studied.

Rahman utilizes four distinct, yet complementary bodies of scholarship to enable his ethnographic assessment

$42 \quad$ Vol. 72000

Journal of Political Ecology 
Reviews

of the Grameen Bank: the "public" and "private" texts of James Scott utilized as "weapons of the weak" and tools of subversion in hierarchical structures; Bourdieu's "practice theory", a constructivist position in which meanings are circulated and constructed through mutually constitutive interactions between structures and individuals; Gramscian hegemonic theory, which discusses the role of ideology in forming and bolstering the system; and Amartya Sen's theory of "entitlements", which examines the ways in which the lack of resources, prevent individual, in particular women, from bargaining and ensuring their security.

Rahman utilizes these theoretical insights to address the hegemonic nature of patriarchal ideology in Bangladesh, and the ways in which it permeates Bank-client (i.e., women), client-client, and intra-household interactions; the everyday subversions used by women in a process that often infantilizes them and reproduces hierarchical social relations in which their entitlements are minimal; and the ways in which Grameen Bank ideology adjusts to the "practical reality of the field." Rahman suggests that the Bank's successes can be attributed partially to its ability to successfully utilize patriarchal structures in facilitating its goals and agendas. At the same time that the Bank seeks to empower women through its loans, it is also recreating and reinforcing patriarchal structures that disempower women.

The book includes informative chapters on "The Study Village and its Socioeconomic Organization," "Microlending and Equitable Development," "Disbursement and Recovery of Loans," and "Microlending and Sustainable Development." To the author's credit these chapters provide richly detailed, nuanced and textured information of the workings of Grameen Bank. Women learning to write and five of them literally shortening their names to facilitate the writing process (90); the inclusion of "sixteen decisions" (social clauses about good living) in the Grameen Bank program (89); the political-social contradictions of servicing women clients through its male Bank workers (84); the time constraints faced by women, and the consequent tensions/violence generated, as they try to fulfill their multiple roles of household service provider and Bank client (120-124); the five women who no longer take new loans from the bank but continue their payments and membership (143); and power hierarchies at work in the village loan center (124) are but a few examples of the rich and telling information provided by the book. The author concludes by pointing out structural weaknesses in Grameen Bank lending (for example the joint liability clause, as well as regular weekly payments that place additional and unrealistic burdens on poor women clients), and by suggesting that "loans alone (which are also debt liabilities), without viable opportunities for women to transform the power relations and create their own spaces in the prevailing power structure, make equitable development and the empowerment of women unattainable in society" (151).

The book has many strengths, including its desire and ability to use four interrelated, yet distinct, theoretical literatures for understanding the workings of the Grameen Bank. Ironically, this is also one of its weaknesses. In his effort to do justice to the demands of the various theoretical underpinnings of his work, Rahman is unable to sufficiently explore and systematically develop any one of them. For example, in Figure 4.7 he provides data on Household Agricultural landholdings in Pas Elshin. These data are very useful in contextualizing the households in terms of poverty and entitlements. However, a more gendered account of entitlements within the household is not consistently provided. The accompanying discussion also suggests that the work was spread too thin.

The author's contention that microlending does not challenge patriarchal structures - rather, it is at time complicit with them, is yet another strength of the book. The author is right in suggesting that the power and tenacity of patriarchal hegemony undermines the empowerment potential of microlending. However, the author presents patriarchal hegemony as an unchanging and inflexible force. Feminist scholarship has documented the chameleon like nature of patriarchy and explored, for example, how patriarchal accommodations accorded to global capital have shifted the nature of discourse in the maquiladoras (Tiano 1994 ). The context of evolving patriarchy and the adjustments of patriarchy with capital and labor needs could have further enriched the discussion of hegemony in the book. Ironically, the book is replete with examples of rule circumvention, partial empowerment of women, and the silent challenges to patriarchy. Unfortunately the author fails to recognize this and does not engage with the complexity of patriarchy.

On a format quibble, a minor point, the book remains too much like a dissertation, following the traditional dissertation format, and failing to exploit the potential of the author's obvious knowledge in a more creative format. On balance, however, this book provides a critical and timely re-reading of microlending. It is a cautionary tale about neo-liberal legends. Readers, policymakers and practitioners interested in the capacity of micro lending to offer empowerment for women will find its caution and analysis insightful.

\section{References Cited:}

Chenery, Hollis, et al., eds.

1974. Redistribution with Growth: Policies to Improve Income Distribution in Developing Countries in 
Reviews

the Context of Economic Growth. London: Oxford University Press.

Tiano, Susan.

1994. Patriarchy on the Line: Labor, Gender, and Ideology in the Mexican Maquila Industry. Philadelphia:

Temple University Press.

\title{
Warmth of the Welcome: The Social and Economic Causes of Economic Success for Immigrants in Different Nations and Cities. By Jeffrey G. Reitz. Boulder: Westview Press (1998), xiii, 298 pp
}

\author{
Reviewed by Marilyn Fernandez, Department of Sociology, Santa Clara University, Santa \\ Clara, CA
}

Jeffrey Reitz sets out to accomplish the daunting task of explaining cross-national and inter-urban variations in the entry-level earnings of new immigrants, mostly immigrants from non-European societies, to the United States, Canada, and Australia. The topic is timely for several reasons. New immigration to these countries can be expected to continue to keep pace with global economic change. The racial/cultural and economic dimensions of immigration have increasingly become part of the public and political debate in these countries. Generally, this debate has centered on the characteristics of the immigrants themselves, as they affect the net economic benefits of immigration, the cost to native-born workers, the burden of the social safety net, and abuse of the immigration system. This book brings a needed social contextual perspective to these discussions.

Using a multiple institutional framework, Reitz explores why immigrants have substantially different entrylevel earnings in the three societies on which he focuses. He sets up a natural experiment to conduct his institutional analyses. The fact that immigrants from the same origin countries or similar racial/ethnic groups have different entry-level earnings depending on whether they moved to the United States, Canada, or Australia, as well as which cities they live in, suggests the need to focus on the institutional context within the countries. Four major institutional sectors - immigration policies, education, labor markets, and social welfare - are treated as autonomous and yet interdependent in their impact on immigrant standing. Why these four institutional sectors? According to Reitz, immigration policies control the entry of newcomers; labor markets directly determine earnings; educational institutions shape the qualification profiles of the native-born with whom the new comers must compete; and welfare services affect immigrant adjustment to their new homes. Despite this heavy institutional orientation, he does not disregard the importance of differences in immigrants from the source countries and the role of the host societies' race relations and attitudes in contributing toward the economic inequalities faced by immigrants. But, given the similarities across the three countries in their potential for discriminatory policies and practices within these institutions, the focus on institutions seems justified.

The book is organized into three parts spanning eight chapters. Part I, which includes two chapters, sets up the theoretical and empirical foundations of the problem. Chapter 1, "Social Causes of the Economic Success of Immigrants," lays out the framework for the institutional analyses and briefly describes the data sources. In Chapter 2, "Immigrant Entry-Level Status in Different Nations and Cities," Reitz uses census data (1980 from the United States and 1981 from Canada and Australia) for the first cohort of immigrants who arrived in the 1970s after the major revamping of the immigration policies of the three host countries. He sets up the problem to be explained as follows: the entry level earnings of the same race/ethnic groups, for example, Black and Chinese immigrants, and Asian immigrants in general, are lower in the United States when compared to Canada and Australia. The earnings of recent immigrants in urban areas of the U.S. (New York, Miami, Boston, San Francisco) are also lower than that of immigrants to cities in Canada or Australia. That these national and cross-urban variations hold for White as well as minority immigrants lends further credence to Reitz's institutional framework. Entry-level immigrant standing is less a product of the characteristics of immigrants and the discrimination they face than they are of the characteristics of the institutional contexts in which they live and work.

$44 \quad$ Vol. 72000

Journal of Political Ecology 